研

ブタンガスによる炉気制御用ガス発生について

足立彰* 山田新太郎”

\title{
Butane Gas For Generating Controlled Atomosphere
}

Akira ADACHI and Shintaro YAMADA

With the progress of petroleum industry the production of liquified gases such as propane and butane has recently been increasing.

Propane gas has already been used for bright annealing of metals, carburization of steel etc., but butane gas has not been utilized yet in our country.

Butane gas has favorable charactristics, such as uniform composition, high thermal power, easy transportation due to steady liquified form and comparatively safe operation due to narrower explosion limits.

This report deals with the investigation of the composition of generated gas from butane, and of the soot deposition in generating endothermic atmosphere.

\section{I . 緒言}

近年石油化学の進歩により高級ガソリン製造の際プロ パン扣よびブタンの如き液化ガスが多量に生産されるに 至つた。プロパンは既に金属の光輝狫鈍, 鋼のガス滠炭 扣よび種々の他の用途に工業的に広く使用されている が、プタンは我が国において未だ工業的に利用されてい ない状態である。ブタンガスの特幑として, 压縮すれば 容易に液化し, 運搬が自由、出来る事, 成分拉よび熱量 が均一であり発熱量が極めて高い事, 爆発限界が狭く比 較的安全である事等が挙げられる。本研究においてはブ タンによる炉気制御用ガス発生について実験を行いブ タン変成ガスの組成および吸熱式ガス発生の際における 蝶の生成の問題について検討した。

\section{II.ブタンの性算}

この実験に使用せるブタンガスは灯油, 軽油, 潤滑油 等を流動接触分解装置飞より接触分解する際に生成され たすので，その組成の一例は次の如くである。

$\begin{array}{lc}\text { プロパン, プロピレン } & 2 \% \\ \text { ブタン, ブチレン } & 97 \% \\ \text { ベンジン } & 1 \% \\ \text { 硫黄分 } & 0.5 \text { grain/100f } \text { P }^{3} \text { 以下 }\end{array}$

第 1 表にはメタン，プロパン拈よびブタンの主なる物 理的性質を示すが，次にこれらの性質の相違について考 えてみる。ブタンは1 分于に4つの炭素原子を含み, 征 つて他のガスに比しその総発熱量は高い。比重について

\footnotetext{
* 大阪大学工学部
}

第1表 メタン,プロパン挔よびブタン の物理的性澌

\begin{tabular}{|c|c|c|c|}
\hline & メ タ & プロパン & ブタン \\
\hline 分子式 & $\mathrm{CH}_{4}$ & $\mathrm{C}_{3} \mathrm{H}_{8}$ & $\mathrm{C}_{4} \mathrm{H}_{\mathrm{i} 0}$ \\
\hline 分子量 & 16.042 & 44.094 & 58.12 \\
\hline 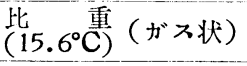 & 0.554 & 1.522 & 2.006 \\
\hline 総発熱量 $\mathrm{kcal} / \mathrm{m}^{3}$ & 9.018 & 22.450 & 29.150 \\
\hline ガス発生量 $\mathrm{m}^{3} / \mathrm{kg}$ & 1.47 & 0.537 & 0.407 \\
\hline $\begin{array}{l}\text { 蒸氛厓 } \mathrm{kg} / \mathrm{cm}^{2} \\
\left(100^{\circ} \mathrm{F}\right)\end{array}$ & & 12.30 & $\quad 2.62$ \\
\hline 沸＼cjkstart点 & -161.4 & -42.1 & -0.50 \\
\hline 臨界温度 & -82.5 & 96.5 & 152.0 \\
\hline 臨界压力 $\mathrm{kg} / \mathrm{cm}^{2}$ & 46.27 & 42.27 & 37.67 \\
\hline
\end{tabular}

はブタンが最大であるが, 同一重量の液化ガスより発生 するガス量は比重の軽いメタンが最大である。メタン， プロパンの沸点は低く, 従つて常温とてこれらを使用す る場合にはガス化し易いが，ブタンは沸点が高くこの点 飞注意を要する。一方臨界温度を比較するとブタンは $152^{\circ} \mathrm{C}$ でプロパンに比し安全で $100^{\circ} \mathrm{C}$ 以上に加熱しても 危険性は少い。第1 図にはブタンおよびプロパンの蒸気 圧と温度との関係を示す。

\section{III. 実験装置および実験方法}

ブタンによる炉気用ガス発生装置は既報(1)(2)(3)のプロ パンによる装置と殆んど同一のものを用いたが, その概 略は第 2 図に示寸如くである。变成炉は長さ $500 m_{m}$ の 


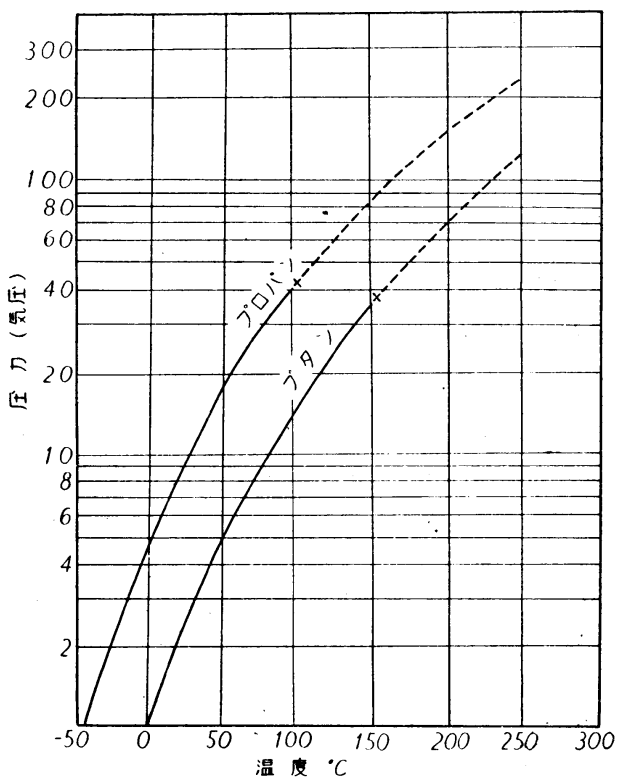

第1図 プロパン括よびブタンの蒸気压

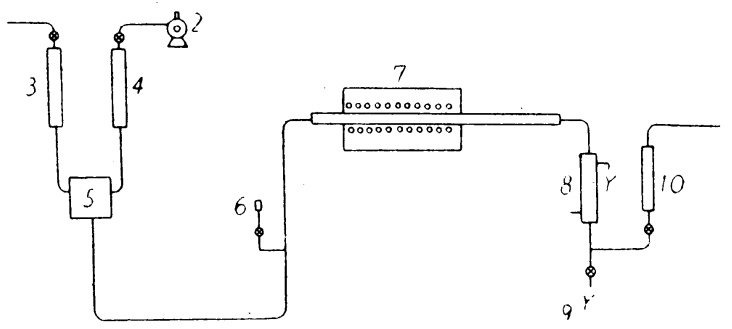

第2図 ブタンによる炉気がス発生装置

$\begin{array}{llcl}1 & \text { ブタンガス } & 6 & \text { 点火ベーナー } \\ 2 & \text { プロワー } & 7 & \text { 変成炉 } \\ 3 & \text { 流量計 (ブタンガス) } & 8 & \text { 椧却器 } \\ 4 & \text { ”（空気) } & 9 & \text { 排水器 } \\ 5 & \text { 混合器 } & 10 & \text { 流最計 (変成がス) }\end{array}$

ニクロム電気炉滋性管 (内径 $32 \phi$, 長さ $1000 \mathrm{~m}$ ) を㨉 入し,この中に吸熱式ガス発生の場合にはニッヶル触媒 を充填し，発熱式ガスの場合には触媒を用いなかつた。 ガス発生方法は, ブタンはボンべより減圧器を通し一定 压力にて取出し空気はブロワーにて送入し，この雨者の 混合比をコックで適当に調整し混合器を経て变成炉へ送 つた。この場合变成炉の温度を $900^{\circ} \mathrm{C}$ 抢よび $1000^{\circ} \mathrm{C}$ に 一定にし，ブタンと空気との混合比を種々に变化させて 変成した時発生するガス組成をオールザットガス分析器 で測定した。

次に吸熱式ガス発生の際起る煤の生成の間題について 研究するため第3図に示寸如き装置を用いた。変成炉は $200 m_{m}$ のニクロム電気炉滋性管(内径 $27 \phi$, 長さ $400 m / m$ ) を挿大し，これに触媒としてアルミナまたはニッケル触

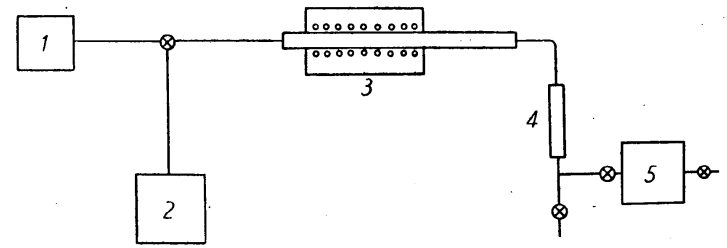

第3図吸熱式がス発生の場合に和ける 煤生成量測定の実験装置

$\begin{array}{llll}1 & \text { 陵装ボス } & 4 & \text { 流星計 } \\ 2 & \text { ブタンと空父の混合がス } & 5 & \text { ガス補集瓶 } \\ 3 & \text { 変成炬 }\end{array}$

媒を充填した。実験方法は空気,ブタンの混合比 10:1の 混合ガスを 1 時間変成炉へ送入し, 次いで酸素を送つて 変成炉内に蓄樍した煤を燃狫させ，この燃狫ガスを一定 量ガラス容器に捕集し, 此の中含まれる一酸化炭素括 よび炭酸ガスを測定し，計算により炉内に蓠䆄した炭素 量を求めた。

\section{IV. 実 験 結 果}

\section{1）ブタンによる変成ガス}

ブタンによる炉気用ガス発生に扣いて，そのガス組 成に影響する因子としては空気とブタンの混合比，变 成温度，ガス流量怙よび触媒等であるが，本実験に括 いてはガス流量を $500 \mathrm{cc} / \mathrm{min}$ 飞一定にし, 触媒とし て吸熱式の場合には ニッヶル, 発熱式には触媒を使用 せずと変成し，その場合空気とブタンの混合比と変成 温度の影響について検討した。

a) 混合比の影響……第 4 図に变成温度 $1000^{\circ} \mathrm{C}$ r て空気とブタンの混合比を種々に変化させた場合に発 生する変成ガスの組成を示す。空気の混合比を増すと 変成ガス中の $\mathrm{CO}_{2}, \mathrm{~N}_{2}$ が増加し, 一方 $\mathrm{CO}, \mathrm{H}_{2}$, $\mathrm{CH}_{4}$ が減少する。混合比 $10: 1$ の場合は吸熱式ガスに, て鋼の汪炭または高炭素鋼の無酸化加熱に使用され，

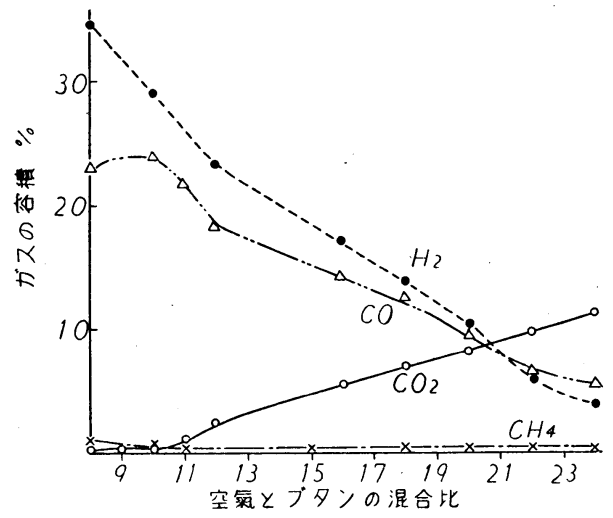

第 4 図 変成温度 $1000^{\circ} \mathrm{C}$ rて空気とブタンの混合比 を棰ふと変化して変成した第合のがス組成 
第2表 ブタンによる変成がス

\begin{tabular}{|c|c|c|c|c|c|c|}
\hline & \multirow{2}{*}{$\begin{array}{l}\text { 空気, } \\
\text { ブタン } \\
\text { 混合比 }\end{array}$} & \multicolumn{2}{|c|}{ が ス } & \multicolumn{2}{|c|}{ 成 分 } & 6 \\
\hline & & $\mathrm{CO}_{2}$ & $\mathrm{CO}$ & $\mathrm{CH}_{4}$ & $\mathrm{H}_{2}$ & $\mathrm{~N}_{2}$ \\
\hline 吸熱式がス & $10: 1$ & 0.1 & 24.2 & 0.6 & 29.1 & bal \\
\hline 発熱甛がス & $17: 1$ & 6.5 & 12.5 & 0.3 & 13.0 & bal \\
\hline
\end{tabular}

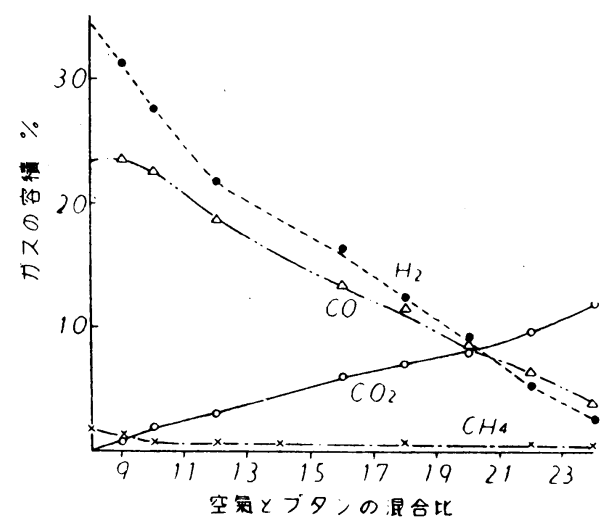

第 5 図変成温度 $900^{\circ} \mathrm{C}$ 亿空気とブタンの混合比 を種々と変化して変成した場合のがス組成

混合比 $17: 1$ のものは発熱式ガスにて鋼の光輝焼入扣よ び低炭素鋼の光輝燒鈍に使用される。第 2 表にこれらの゙ ガス組成を示す。第 5 図に変成温度 $900^{\circ} \mathrm{C}$ 亿空気とブ タンの混合比を変えた場合に扣ける変成ガスのガス組成 を示す。

b）変成温度の影響……変成ガスの組成に牤よぼす変 成温度の影響を見るため, 変成温度を打の扣の $800^{\circ} \mathrm{C}$, $900^{\circ} \mathrm{C}$ 拐よび $1000^{\circ} \mathrm{C}$ 場合につきガス分析を行つたが第 4 図扣よび第5図より明らかなよ 5 亿変成温度により大 なる変化は現われないが，一般に変成温度が高くなると 共に変成ガス中の $\mathrm{CO}, \mathrm{H}_{2}$ が増加し $\mathrm{CO}_{2}$ が減少する。

2）変成ガス発生量

空気とブタンの混合此 10:1 の吸熱式ガス発生の場合 について考えると

$\mathrm{C}_{4} \mathrm{H}_{10}+10\left(1 / 5 \mathrm{O}_{2}+4 / 5 \mathrm{~N}_{2}\right)=4 \mathrm{CO}+5 \mathrm{H}_{2}+8 \mathrm{~N}_{2}$

の如くブタンガス 1 モルに対し吸熱式ガス 17 モルが得 られる。プロパンを変成すると空気とプロパンの混合比 7.5: 1 の場合プロパン 1 モルに対し吸熱式ガス 13 モル が得られ，ブタンの場合に比しそのガス発生量が小であ る。また発熱式ガスについて類似ガス組成を得るための 空気ガス混合比をブタンとプロパンについて比較すると ブタンの場合は $17: 1$ であるがプロパンの場合は $13: 1$ であり, 吸熱式の場合と同样ブタンの方がより効果的で ある。

3）谋の生成

吸熱式ガスは空気とブタンの混合比 $10: 1$ の混合ガス の触媒を充填せる変成炉に送つて発生されるが, 此の場 合長時間ガスを流すと変成炉のレトルト内と煤が多量に
蓄皘し, 終りにはレトルトが開塞しガスが流れなくなる 場合が起る。このような煤の発生の原因となる内子につ いては種々考えられるが，そのうち主なものはブタンの ガス組成, 空気とブタンの混合比, ガス沙通時間, 変成 温度, 触媒の種類扣よびその活性度, 炉の棈造等であ る。本実験に扣いては空気とブタンの混合比尔 $10: 1$ と し,ガスの流通時間を一定にし变成炉の变成温度および 触煤の影響について研究した。

a ）変成温度の影響……ガス発生炉飞扣ける变成温度 が炉内に扣ける谋の生成に扣よぼす影響を調べるため变 成温度を種々変化させ，吸熱式ガスを1時間流した場合 変成炉内に蓄積せる煤の量を測定したが，その結果は 第6図に示寸通りである。この央験結果によるとアルミ

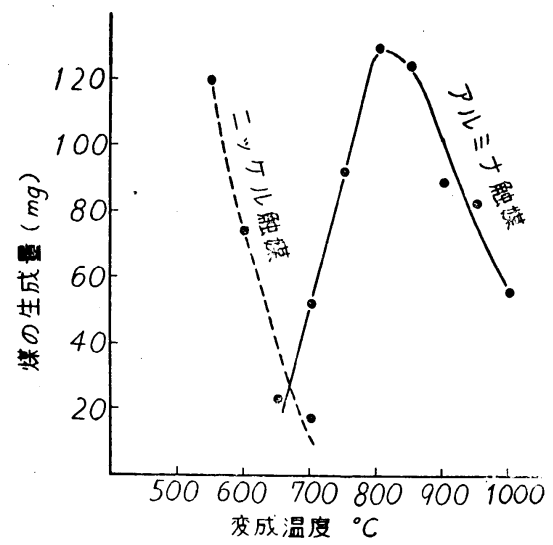

第6図吸熱式がス発生の際に括ける変成 温度と炬内の煤生成量との関係

ナ触媒を用いた場合 $650^{\circ} \mathrm{C}$ 附近では某は殆んど生成せず 変成温度がこれより上昇すると共に煤の生成量は急激に 増加し $800^{\circ} \mathrm{C}$ 附近で最高になり，これより変成温度が 高くなると煤は漸次減少するに至る。吸熱式ガスが変成 炉内に入つた場合生ずる化学反応は非常に複雑であるが まず $\mathrm{C}_{4} \mathrm{H}_{10}$ の解離が起り，次いで空気中の酸素と反応し てガスの变成が行われると考えられる。 $\mathrm{C}_{4} \mathrm{H}_{10}$ は解離し て種々な炭化水素, 水素扣よび遊離の炭素を生成するが 钻極には次の式のように分解すると考えられる。

$$
\begin{aligned}
& \mathrm{C}_{4} \mathrm{H}_{10} \rightarrow l \mathrm{C}+m \mathrm{H}_{2}+n \mathrm{CH}_{4} \\
& \mathrm{CH}_{4}=\mathrm{C}+2 \mathrm{H}_{2}
\end{aligned}
$$

次に空気中の酸素との主なる反応は

$$
\begin{aligned}
& 2 \mathrm{H}_{2}+\mathrm{O}_{2}=2 \mathrm{H}_{2} \mathrm{O} \\
& \mathrm{C}+\mathrm{O}_{2}=\mathrm{CO}_{2} \\
& \mathrm{CH}_{4}+\mathrm{O}_{2}=\mathrm{CO}_{2}+\mathrm{H}_{2} \mathrm{O} \\
& 2 \mathrm{C}+\mathrm{O}_{2}=2 \mathrm{CO} \\
& \mathrm{C}+\mathrm{CO}_{2}=2 \mathrm{CO} \\
& \mathrm{C}+\mathrm{H}_{2} \mathrm{O}=\mathrm{CO}+\mathrm{H}_{2} \\
& \mathrm{CO}_{2}+\mathrm{H}_{2}=\mathrm{CO}+\mathrm{H}_{2} \mathrm{O}
\end{aligned}
$$


と考えられる。変成炉の温度が低い場合には (1) (2) の反 応が進まず，また少量分解しても(3)(4) (5) の反応が起り 遊離の炭素即ち煤が認められない。変成温度が上皁する そ (1) (2) の反応速度が急激汇增加し分解が進むが，酸素 が不充分なため (3) (4) (5) の反応は充分進行出来ず，また (6) (7) (8) の反応子温度が未だ高くないので充分進まず, 從つて煤の発生量が最大になる。更と変成温度が商くな ると (6) (7)(8) の反応が進み, 变成ガス中に CO 捛よび $\mathrm{H}_{2}$ が増㞦し，反対に炉内に蓄積する煤の量が漸次娍少 すると考えられる。

b ）触媒の影響……つぎと变成炉内にニッヶル触媒を 用いた場合には煤の発生量の最高点が低温㒋に移り, 変 成温度 $800^{\circ} \mathrm{C}$ 附近で媒の生成が認められなくなつた。こ れは触煤の作用により低温で (1) の反応が促進される結 果, $500^{\circ} \mathrm{C}$ 以下の温度で既飞分解が進み，末た一方(6) (7) (8)の反応す比較的低温で進行する結果と考えられる。

\section{$\mathrm{V}$. 総 括}

以上ブタンによる炕短制御用ガス発生の際と括けるガ ス組成执よび吸熱式ガス発生の場合に扣ける谋の生成の 間題につき実験を行つたその結果の大要は次の如くで女
る。

（1）ブタンを空気と共に変成することにより常に一定組 成の炉気用ガスが発生される。

(2) 空気とブタンの混合比 10：1 亿て変成することとよ り吸熱式ガス, 混合比 17:1 反て発熱式ガスが発生さ れる。

（3）同一ガス量のブタン末たはプロパンを変成した場合 ブタン変成ガス発生量はプロパンより大である。

（4）吸熱式ガス発生の際変成炉内に拈ける煤の生成量飞 は極大になる変成温度があり，これにより温度が高く なると煤の量は漸次減少する。

(5) ニッグ触煤はガスの変成を促進する結果, 煤生成 量が極大になる变成温度を低下せしめる。

(1956.1.18 受理)

\section{交献}

(1) 足立彰, 山田新太郎, 鋼材の光輝熱処理 金属表面技術， 6 (1955）40

（2）足立彰, 山田新太郎, 日本金属学会誌, 19 (1955) 1

（3）足立彰, 山田新太郎, 粉生宗幸, 原泰三, 肥田敏雄, 鉄と鋼，41（1955） 124

\title{
軽油およびガソリンによる保護ガスの発生について
}

\author{
足立彰* 山田新太郎* 尾崎圭三*
}

\section{Kerosene and Gasoline for Generating Controlled Atmosphere}

Akira ADACHI, Shintaro YAMADA and Keizo OZAKI

For genarating the controlled atmospheres in heat-treatment of metals, propane gas and charcoal gas is now widely used because of easy availability and simple method of generating. Kerosene and gasoline are also considered as the useful resources for generating furnace atmospheres, because they have various favorable characteristics that they are inexpensive as compared with other fuels that their transportation is easy, and that they can be obtained in the inconvenient districts where fuel gases are not secured.

This, report deals with the studies on generating conversion gases from kerosene and gasoline, and controling their compositions for the possible utilization of the atmospheres from them to the bright annealing of metals.

\section{I 、緒言}

近年急速なる発展を示した調制雾囲気内における熱処 理において，その雾囲気ガス原料としては現在主として プロパンガス，都市ガス，木炭ガス等が用いられている が, これは上記のガス体燃料が比較的入手し易く, かつ

$*$ 大阪大学工学部
発生法が容易であることによる。今この雼刑気ガス原料 として軽油, ガソリン等の液体然料を用いることができ れば，これらはガス体然料に対し比較的安洒にして運搬 飞便利, 取扱が容易で，またガス体然料の入手困難な地 方でも容易飞購入できるという利点を有す。我々はこの 点飞着眼して軽油乱よびガりリンを熱分解変成し発生ガ ス組成の制御を試みると共にそのガスを用いて焼鈍実験 